\title{
Regeneration and Genetic Transformation of Arabidopsis Pumila. An Ephemeral Plant Suitable for Investigating the Mechanisms for Adaptation to Desert Environments
}

\author{
Yuhuan Jin \\ Shihezi University College of Life Sciences \\ Li Guo \\ Shihezi University College of Life Sciences \\ Danqing Liu \\ Shihezi University College of Agriculture

\section{Yongguang Li} \\ Shihezi University College of Life Sciences \\ Hao Ai
}

Anhui University of Science and Technology College of Agriculture

xianzhong Huang ( $\sim$ huangxz@ahstu.edu.cn )

Anhui Science and Technology University https://orcid.org/0000-0003-1264-8106

\section{Research Article}

Keywords: Arabidopsis pumila, Tissue culture, Regeneration, Agrobacterium tumefaciens, Genetic transformation

Posted Date: February 10th, 2021

DOI: https://doi.org/10.21203/rs.3.rs-160586/v1

License: (9) This work is licensed under a Creative Commons Attribution 4.0 International License. Read Full License 


\section{Abstract}

Arabidopsis pumila is a type of cruciferous ephemeral plant, which in China mainly grows in the desert environments of northern Xinjiang. A. pumila not only has a short growth duration, but also has high photosynthetic efficiency, seed yield, salt tolerance, and drought resistance. It is an ideal species for the study of environmental adaptations in ephemeral plants. We induced callus tissue formation on the roots and hypocotyls of 8-day-old seedlings, and on the leaves and petioles of 4-week-old seedlings, and obtained multiple adventitious shoots on these tissues grown on Murashige and Skoog induction medium supplemented with $0.5 \mathrm{mg} / \mathrm{L}$ 6-Benzylaminopurine and $0.1 \mathrm{mg} / \mathrm{L}$ a-Naphthalene acetic acid. Young roots, hypocotyls, leaves, and petioles could all induce calluses, but the induction rate was highest on young roots. In addition, the leaves and petioles of 4-week-old seedlings were used as explants, the $\Delta 1$-pyrroline-5-carboxylic acid synthase gene 1 of $A$. pumila controlled by $35 S$ promoter of cauliflower mosaic virus was used as target gene, and hygromycin $B$ was used as screening antibiotic to explore Agrobacterium tumefaciens GV3101 mediated transformation. The results showed that the callus induction rate of petiole explants was the highest when they were treated with Agrobacterium suspension $\left(\mathrm{OD}_{600}=0.6\right)$ for $10 \mathrm{~min}$ and thenco-cultured in dark for $2 \mathrm{~d}$. The qRT-PCR results showed that the ApP5CS1.1 gene was overexpressed in the transgenic plants. These protocols provide working research methods for exploring the cellular level adaptative mechanisms of this species to desert environments.

\section{Key Message}

Establishment of tissue culture in ephemeral plant Arabidopsis pumila and efficient Agrobacteriummediated genetic transformation for investigating the mechanisms for adaptation to desert environments.

\section{Introduction}

Efficient in vitro plant propagation and genetic transformation techniques are the key to effective fundamental and applied plant research. However, establishing stable genetic transformation techniques in plants remains challenging. At present, Agrobacterium transformation is still the leading transformation technique, and is common in many research areas such as investigations into plant gene function (Bertier et al. 2018; Lee et al. 2019), crop breeding and improvement (Gerszberg et al. 2015; Gambhir et al. 2017), rapid propagation and cultivation of commercial plants (Weckx et al. 2019), germplasm preservation of certain vegetatively propagated plants (Bömer et al. 2019), and rescue of rare/endangered plant species (Sadeq et al. 2016). In addition, certain plant cell and organ cultures can produce secondary metabolites for use in industry and medicine (Lu et al. 2016; Tatsis and O'Connor 2016; Loyola-Vargas and Ochoa-Alejo 2018). Omics research (i.e., genome, proteome, transcriptome, and metabolome) combined with tissue culture technologies provides a powerful means of understanding the complex developmental processes of plants (Imin et al. 2005; Wickramasuriya et al. 2015; Loyola-Vargas and Ochoa-Alejo 2018). 
In recent years, there has been an increasing number of studies on regeneration and cultivation techniques for different plants, especially crops such as soybean (Glycine max) (Raza et al. 2017, 2019), corn (Zea mays) (Garrocho-Villegas et al. 2012), cabbage (Brassica oleracea) (Kumar et al. 2015), sugar beet (Beta vulgaris) (Kagami et al. 2016), coriander (Coriandrum sativum) (Ali et al. 2017), and potato (Solanum tuberosum) (Fossi et al. 2019). Agrobacterium-mediated genetic transformation techniques allow the production of transgenic plants and require genetic engineering methods using plant regeneration systems (Cao et al. 2018; Li et al. 2019; Wang et al. 2019). Agrobacterium-mediated gene transformation has obvious advantages compared with other gene transformation methods. It is relatively cheap and fast to perform and allows: the transfer of large fragments of DNA; the integration of low copy number transgenes; the ability to efficiently and stably integrate genes into the nuclear genome; and the preferential insertion of transcriptional activity zones (Cha et al. 2012; Gasparis 2017; Bruce et al. 2019). Agrobacterium-mediated genetic transformation techniques based on tissue culture have been developed for many plants, including strawberry (Fragaria vesca) (Oosumi et al. 2006), rice (Oryza sativa) (Hiei et al. 2008; Saika et al. 2010), wheat (Triticum aestivum) (Hu et al. 2003), corn (Zhong et al. 2018), sorghum (Sorghum bicolor) (Kuriyama et al. 2019), hybridized poplar (Populus Alba $\times$ Populus glandulosa Uyeki) (Song et al. 2019), and Prymnesiophycae such as Isochrysis galbana (Prasad et al. 2014).

The current most widely used gene editing technologies also rely to a great extent on tissue culture and Agrobacterium-mediated transformation technologies, which can directly edit the plant genome at a specific site without introducing foreign genes. This technology has produced good mutants of tomato (Solanum lycopersicum) (Soyk et al. 2017), wheat (Wang et al. 2014), rice (Li et al. 2016; Srivastava et al. 2017), corn (Feng et al. 2016), and other crops.

Ephemeral plants have only one or several generations each year, and only sprout and grow during favorable periods (i.e., when sufficient water is available) and can survive unfavorable periods as seeds (Shi et al. 2006). In China, ephemeral plants are mainly distributed in the deserts of the Junggar Basin and the Ili River Valley in northern Xinjiang, bordering the eastern edge of the Junggar Basin (Shi et al. 2006; Huang et al. 2017). They germinate in mid-March or early April using rainwater and snowmelt from the Tianshan Mountains and complete their life cycle about two months later in mid-June. This period includes the season with the strongest winds in the northern Xinjiang deserts. Therefore, ephemeral plants play an important role as windbreaks stabilizing sandy soils, conserving soil and water, and improving microhabitat quality (Shi et al. 2006; Jin et al. 2019). They are subject to a variety of harsh environments during their life cycle, including extreme temperature, drought, and high soil salinity. Soil salinity is one of the main abiotic factors restricting plant growth and crop production. Therefore, understanding the genetic basis of plant salt tolerance in plants, especially in crops, is an extremely important area of research. The extremely harsh ecological environment in Xinjiang means that many salt-tolerant and drought-resistant organisms inhabit its saline and semi-saline soils. Among them, Arabidopsis pumila is a short-lived desert plant which grows quickly in the brief favorable season when the rain falls and snows melt in early spring, and benefits from its fast growth, high yield, high photosynthetic efficiency, and stress tolerance (Tu et al. 2016; Jin et al. 2019). Understanding the 
molecular mechanism behind $A$. pumila's rapid growth and adaptations to harsh environments is therefore of great significance in protecting and using its stress tolerant genes to improve crop resistance.

We constructed a cDNA library of $A$. pumila seedlings, carried out sequencing analysis of expressed sequence tags, and cloned a number of salt-tolerant-related genes such as the $\mathrm{H}^{+}$inorganic pyrophosphatase gene, the delta-1-pyrroline-5-carboxylic acid synthase 1 (P5CS1) gene, and the $\mathrm{Na}^{+} / \mathrm{H}^{+}$ antiporter (Zhao et al. 2013; Huang et al. 2017). Transcriptome sequencing analysis of A. pumila seedlings stressed with $250 \mathrm{mM} \mathrm{NaCl}$ revealed that many salt stress-responsive genes showed dynamic changes. These results will enable a better understanding of the salt adaptation mechanisms of shortlived plants, such as proline metabolism which enables plants to respond to certain abiotic stresses (Yang et al. 2018).

A large amount of proline accumulates in plants under abiotic stress conditions, such as drought, high salt levels, strong light, and oxidative stress (Szabados et al. 2010). P5CS participates in catalyzing the first step of proline synthesis in which it acts as the rate-limiting enzyme (Anton et al. 2020). We found that the ApP5CS1 homologous gene actively responds to high salt stress (Huang et al. 2017) (Supplementary Fig. 1), suggesting that P5CS1 also plays an important role in A. pumila's salt tolerance response. In-depth study of gene function can better explain the adaptive mechanisms enabling $A$. pumila to grow in desert environments. Although many important salt-tolerant genes are known, detailed studies of gene function in A. pumila have been limited due to the lack of suitable tissue culture and transformation techniques. The establishment of a tissue culture regeneration system for $A$. pumila is therefore important for exploring the cellular level adaptative mechanisms and evolution of this species in desert environments. Understanding these issues will bring significant improvements to modern biotechnology, the development of genetic resources, and the preservation of germplasm.

\section{Materials And Methods}

\section{Plant materials}

Arabidopsis pumila seeds were preserved in our laboratory. The seeds were sterilized by rinsing with absolute ethanol for $1 \mathrm{~min}$, and then with $20 \%$ sodium hypochlorite for $10 \mathrm{~min}$, and finally with sterile water six times. Sterilized seeds were sown on Murashige and Skoog (MS) agar medium with $3.0 \%(\mathrm{w} / \mathrm{v})$ sucrose and $0.8 \%(\mathrm{w} / \mathrm{v})$ plant agar added. Seedlings were grown in climate-controlled conditions at $22 \pm$ $1{ }^{\circ} \mathrm{C}, 300 \mu \mathrm{mol} \mathrm{m} \mathrm{m}^{-2} \mathrm{~S}^{-1}$ of light intensity, 16 hours light/8 hours dark, and $70 \%$ relative humidity. Pieces of young root (1 cm long, Fig. $1 \mathrm{a}, \mathrm{c})$, hypocotyl (1 cm long, Fig. $1 \mathrm{a}, \mathrm{b})$, leaf $\left(1 \mathrm{~cm}^{2}\right.$, Fig. $\left.1 \mathrm{~d}, \mathrm{e}\right)$ and petiole $(1 \mathrm{~cm}$ long, Fig.1d, e) tissue were collected from 8-day-old and 30-day-old seedlings to serve as explants (Fig. 1).

\section{Adventitious shoot induction}


Adventitious shoots were induced under conditions of $22 \pm 1{ }^{\circ} \mathrm{C}, 300 \mu \mathrm{mol} \mathrm{m} \mathrm{m}^{-2} \mathrm{~S}^{-1}$ light intensity and $70 \%$ relative humidity. Explants of young root, hypocotyl, leaf, and petiole were cultivated on induction medium containing $0.5 \mathrm{mg} / \mathrm{L}$ 6-Benzylaminopurine (6-BA) and $0.1 \mathrm{mg} / \mathrm{L}$ a-Naphthalene acetic acid (NAA).

The induction medium was supplemented with $3.0 \%(\mathrm{w} / \mathrm{v})$ sucrose and $0.8 \%(\mathrm{w} / \mathrm{v})$ agar powder, and the $\mathrm{pH}$ was adjusted to 5.8 . The medium was autoclaved at $121^{\circ} \mathrm{C}$ for $20 \mathrm{~min}$ and then cooled to $55^{\circ} \mathrm{C}$ before adding the plant hormones, and was finally placed into $150 \mathrm{~mL}$ sterilized flasks (about $25 \mathrm{~mL}$ per flask). The basic MS medium and hormones (6-BA and NAA) used in this study were purchased from Beijing Boao Tuoda Biotechnology Co., Ltd. (Boao Tuoda, Beijing, China).

\section{Root induction and plant domestication}

The elongated adventitious shoots $(1-2 \mathrm{~cm})$ were transferred for cultivation to MS medium (pH 5.8) containing $0.1 \mathrm{mg} / \mathrm{L} \mathrm{NAA}$ and $500 \mathrm{mg} / \mathrm{L}$ carbenicillin (Carbenicillin, Carb) at $22 \pm 1{ }^{\circ} \mathrm{C}$ with a $16 / 8 \mathrm{~h}$ (light/dark) photoperiod with $300 \mu \mathrm{mol} \mathrm{m} \mathrm{m}^{-2} \mathrm{~S}^{-1}$ light intensity until roots were induced. In order to adapt the cuttings to the growth environment, the flasks containing the test tube plantlets were moved from the culture room to a greenhouse for 4-5 d. The seedlings were then carefully removed from the flasks, rinsed with tap water, and transferred to a culture pot containing 1:1 $(w / W)$ nutrient soil to vermiculite.

\section{Agrobacterium culture and transformation process}

Based on previous studies of the full-length transcriptome of $A$. pumila under salt stress, it was found that two P5CShomologous genes exhibited elevated expression characteristics while under salt stress (Yang et al. 2018) (Supplementary Fig. 1). We cloned the P5CS1.1 gene, and after sequencing (the length of ORF is $2154 \mathrm{bp}$ ), and then connected it to the hygromycin-resistant $P C A M B I A 1301$ vector. After double digestion with $\mathrm{Ncol}$ and Bst Ell to verify the plasmid, the correctly constructed 35S:ApP5CS1.1 vector plasmid (Supplementary Fig. 2) was transferred into Agrobacterium tumefaciens GV3101. A single colony of Agrobacterium tumefaciens was cultured at $28^{\circ} \mathrm{C}$ in Luria-Bertani liquid medium containing 50 $\mathrm{mg} / \mathrm{L}$ kanamycin, $25 \mathrm{mg} / \mathrm{L}$ rifampicin, and $50 \mathrm{mg} / \mathrm{L}$ gentamicin until the culture density reached an $\mathrm{OD}_{600}$ of 0.8 . Agrobacterium tumefaciens cells were obtained by centrifugation at $5000 \mathrm{rpm}$ for $10 \mathrm{~min}$, and the cells were suspended in a 1/2 MS solution (pH 5.8) containing $3.0 \%(\mathrm{w} / \mathrm{v})$ sucrose and $20 \mathrm{mg} / \mathrm{L}$ acetosyringone.

The petiole and leaf explants were cut on an ultra-clean workbench and infected in infection solution of $\mathrm{OD}_{600}=0.6$ for $5 \mathrm{~min}$ and $10 \mathrm{~min}$, and an infection solution with $\mathrm{OD}_{600}=1.0$ for $5 \mathrm{~min}$ and $10 \mathrm{~min}$, respectively. The experimental design comprised a total of four treatments, each with three replicates. Sterile filter paper was used to absorb excess bacteria, and the samples were incubated on symbiotic medium (MS basal medium containing $0.5 \mathrm{mg} / \mathrm{L}$ 6-BA, $0.1 \mathrm{mg} / \mathrm{L} \mathrm{NAA}$, and $20 \mathrm{mg} / \mathrm{L} \mathrm{AS}$; pH 5.8) for $2 \mathrm{~d}$ in the dark. The petiole and leaf explants were then transferred to selection medium (MS basal medium 
containing $0.5 \mathrm{mg} / \mathrm{L}$ 6-BA, $0.1 \mathrm{mg} / \mathrm{L}$ NAA, $10 \mathrm{mg} / \mathrm{L}$ Hygromycin B, and $500 \mathrm{mg} / \mathrm{L} \mathrm{Carb;} \mathrm{pH}$ 5.8) for shoot induction. The samples were transferred to fresh selection medium once a week. The induction status of the calluses and adventitious shoots were recorded every $7 \mathrm{~d}$ during the culture period. The shoot samples (1-2 cm long) were then cut and transferred to MS agar medium (pH 5.8) and supplemented with $0.1 \mathrm{mg} / \mathrm{L} \mathrm{NAA}$ and $500 \mathrm{mg} / \mathrm{L}$ Carb for root induction.

\section{Genomic DNA extraction and PCR identification}

The genomic DNA was isolated from leaves of transgenic and wild-type $A$. pumila plants via the Fastpure plant DNA isolation Mini Kit (Vazyme, Nanjing, China). For PCR analyses, the forward primer 5'ATGGAGGAGCTAGATCGTTCA-3', reverse primer 5'-TTAGGCTTGGATGGGAATGTC-3' were designed according to the CDS of ApP5CS1.1 (GenBank accession number: MW227238). The final reaction mixture $(20 \mu \mathrm{L})$ contained $2 \mu \mathrm{L} 10 \times$ Taq buffer, $1.5 \mu \mathrm{L} 2.5 \mathrm{mmol} / \mathrm{L}$ dNTP, $0.5 \mu \mathrm{L}$ forward and reverse primers respectively, $0.5 \mu \mathrm{L}$ Taq DNA polymerase (Takara, Dalian, China), and $\mathrm{dd}_{2} \mathrm{O}$ supplement. The reaction conditions were $94^{\circ} \mathrm{C} 2 \mathrm{~min}$, followed by 35 cycles of $30 \mathrm{~s}$ at $94^{\circ} \mathrm{C}, 30 \mathrm{~s}$ at $56^{\circ} \mathrm{C}, 2 \mathrm{~min} 20 \mathrm{~s}$ at $72{ }^{\circ} \mathrm{C}$, and $72{ }^{\circ} \mathrm{C} 10 \mathrm{~min}$ for extension.

\section{Quantitative real-time PCR (qRT-PCR) assays}

The seedlings of wild type and transgenic $A$. pumila plants were collected and immediately stored in liquid nitrogen. Total RNA was extracted using RNAprep Pure Plant Kit (Tiangen, Beijing, China) according to the manufacturer's instructions. After purification using DNase without RNase (Tiangen, Beijing, China), the cDNA synthesis reactions were performed using the PrimeScript II first Strand cDNA Synthesis Kit MIX (Bioteke, Beijing, China) following the manufacturer's instructions with $300 \mathrm{ng}$ of total RNA per reaction. qRT-PCR was carried out on an Applied Biosystems 7500/7500-Fast Real-Time PCR system (ABI, Foster City, CA, United States) with the $2 \times$ ChamQ Universal SYBR Green qPCR Master Mix (Vazyme, Nanjing, China). The conditions of PCR were performed according the methods by Huang et al. (2017). The gene-specific forward primer of ApP5CS1.1 was 5'-GGAAGAATCGTTGGTGGCTC-3', and the reverse primer was 5'-ACAAGTGCATCAGGTCGAGA-3'. Glyceraldehyde-3-phosphate dehydrogenase gene (MW227237) was used as an internal reference control (Jin et al. 2019). Three biological replicates were performed with RNA isolated independently and each RT reaction had three replicates. The initial denaturation time was $94^{\circ} \mathrm{C} 30 \mathrm{~s}$, followed by 40 cycles at $95^{\circ} \mathrm{C} 15 \mathrm{~s}, 60^{\circ} \mathrm{C} 15 \mathrm{~s}, 72{ }^{\circ} \mathrm{C} 15 \mathrm{~s}$, and finally extended at $72{ }^{\circ} \mathrm{C}$ for $10 \mathrm{~min}$. The relative gene expression levels were calculated by $2^{-\Delta \Delta C t}$ method (livak and schmittgen 2001).

\section{Results}

Regeneration induction of four different explants of A. pumila 
Young root, hypocotyl, leaf, and petiole explants were cultured in MS induction medium containing 0.5 $\mathrm{mg} / \mathrm{L} 6-\mathrm{BA}$ and $0.1 \mathrm{mg} / \mathrm{L}$ NAA. Of the four explant tissues, roots showed the highest callus induction rate (99.42\%), followed by petioles $(97.04 \%)$ and leaves $(96.58 \%)$, while hypocotyls had the lowest callus induction rate $(93.53 \%)$ (Table 1$)$.

Table 1

Callus formation and adventitious bud induction rates of four different explants from A. pumila

\begin{tabular}{|c|c|c|c|c|c|c|c|}
\hline Explants & $\begin{array}{l}\text { Total } \\
\text { number }\end{array}$ & $\begin{array}{l}\text { Callus } \\
\text { number }\end{array}$ & $\begin{array}{l}\text { Induction } \\
\text { rate (\%) }\end{array}$ & $\begin{array}{l}\text { Shoot } \\
\text { formation } \\
\text { number }\end{array}$ & $\begin{array}{l}\text { Shoot } \\
\text { formation } \\
(\%)\end{array}$ & $\begin{array}{l}\text { Callus } \\
\text { formation } \\
\text { (d) }\end{array}$ & $\begin{array}{l}\text { Shoot } \\
\text { Formation } \\
\text { (d) }\end{array}$ \\
\hline Youg root & 343 & 341 & 99.42 & 335 & 97.7 & $\begin{array}{l}7.33 \pm \\
0.48^{d}\end{array}$ & $32 \pm 2.15^{d}$ \\
\hline hypocotyl & 232 & 217 & 93.53 & 208 & 89.7 & $\begin{array}{l}10.05 \pm \\
0.74^{c}\end{array}$ & $\begin{array}{l}59.05 \pm \\
2.16^{\mathrm{a}}\end{array}$ \\
\hline petiole & 405 & 393 & 97.04 & 356 & 87.9 & $\begin{array}{l}13.24 \pm \\
0.77^{a}\end{array}$ & $\begin{array}{l}44.25 \pm \\
4.07^{b}\end{array}$ \\
\hline leaf & 322 & 311 & 96.58 & 298 & 92.5 & $\begin{array}{l}12.76 \pm \\
0.77^{b}\end{array}$ & $\begin{array}{l}41.95 \pm \\
2.37^{c}\end{array}$ \\
\hline
\end{tabular}

\section{Young Roots}

The young white root explants began to form calluses after one week on the induction medium (Table 1); somatic embryos formed at the cuts at both ends of the explants, and the embryogenic callus appeared green, spherical, and clustered (Fig. 2a). Embryogenesis of somatic cells is asynchronous and can occur anywhere on the explant after 7-20 d of induced culture. After $20 \mathrm{~d}$ of callus induction, 341 of 343 explants were successfully induced, and the total callus induction rate was $99.42 \%$. At $30 \mathrm{~d}$ after induction, embryogenic calluses began to form adventitious shoots (Fig. 2b). The number of explants inducing adventitious shoots was 335 , accounting for $97.7 \%$ of all explants (Table 1 ). The adventitious shoots (1-2 cm long) were cut off and transferred to a flask containing rooting medium to induce rooting. Rooting occurred after about $20 \mathrm{~d}$ (Fig. 2c, d). Regenerated seedlings with strong roots eventually grew into complete plants (Fig. 2e, f).

\section{Hypocotyls}

Arabidiopsis pumila hypocotyl explants were incubated on induction medium for about $10 \mathrm{~d}$ to form embryogenic calluses. Embryogenic calluses generally appeared on the cut surface of the explant, or 
along the sides in contact with the culture medium (Fig. 3a). Some somatic embryos formed shoots on the upper surface of the explants, and clustered shoots produced roots (Fig. 3b). Of the 232 hypocotyl explants, a total of 217 were induced to form calluses, and the callus induction rate was $93.53 \%$ (Table 1). Adventitious shoots on hypocotyls began to form after explants had been cultured for about two months, and the adventitious shoot induction rate was $89.7 \%$ (Table 1). The adventitious shoots (1$2 \mathrm{~cm}$ long) were cut off and transferred to a rooting induction medium to induce the rooting process (Fig. 3c). Regenerated shoots with many strong roots were able to grow into complete plants (Fig. 3d).

\section{Petioles}

Embryogenic calluses were observed on petiole explants after $13 \mathrm{~d}$ of culture on induction medium. Green embryogenic callus cell clusters formed at the point of incision of the explants, and these embryos developed well. The petiole tissues of $A$. pumila can form a large number of healthy green embryogenic calluses after about $20 \mathrm{~d}$ (Fig. 3e). Of the 405 petiole explants, 393 were successfully induced to produce adventitious shoots, and the callus induction rate was $97.04 \%$ (Table 1). The calluses began to form adventitious shoots after about $\mathbf{4 4} \mathrm{d}$, and the adventitious shoot induction rate was $\mathbf{8 7 . 9 \%}$ (Fig. $3 \mathrm{f}$, Table 1). Adventitious shoots were transferred to rooting medium to induce rooting (Fig. $3 g$ ) until strong root systems and complete plants developed (Fig. 3h, 3k, and 3l).

\section{Leaves}

The leaf explants swelled and bent after $12 \mathrm{~d}$ of induction culture, and somatic embryos were formed directly at the cut edges of the explants (Fig. 3i). Embryonic cells appeared in green globular clusters. However, somatic embryogenesis was asynchronous, varying over two to six weeks. Some embryos germinated on the starting medium, or when subcultured on the same fresh medium, and proliferated into larger embryos by producing secondary embryos (Fig. 3i). Of 322 leaf explants, 311 successfully induced calluses, and the callus induction rate was $96.58 \%$ (Table 1). After forming sufficient calluses, callus was further induced to produce adventitious shoots after about $42 \mathrm{~d}$ (Fig. 3j), with an induction rate of $92.5 \%$. The adventitious shoots appeared earlier, and at a higher induction rate, than on the petioles (Table 1). Adventitious shoots (1-2 cm long) were cut and transferred to a rooting medium to induce rooting and sufficient strong roots were produced to enable growth into complete plants (Fig. 3k, I).

Establishment of an A. pumila genetic transformation system

We optimized the concentration and duration of Agrobacterium infection during the transformation process. At an $\mathrm{OD}_{600}$ of 0.6 , infection for 10 min produced a higher callus induction rate than infection for $5 \mathrm{~min}$, for both petiole and leaf explants. On the contrary, when the $\mathrm{OD}_{600}$ was 1.0 , the callus induction rate was lower (Table 2). Of the four treatments, $\mathrm{OD}_{600}$ at 0.6 with an infection time of 10 min produced a petiole explant callus percentage of $34.23 \%$, significantly higher than that of the other three treatments. 
The percentage of callus formation on leaf explants was highest $(31.23 \%)$ at $\mathrm{OD}_{600}$ at 1.0 with an infection time for $5 \mathrm{~min}$.

Table 2

Leaf and petiole explants were treated with different concentrations of infection solution

\begin{tabular}{|c|c|c|c|c|c|c|}
\hline \multirow[t]{2}{*}{ Concentration/Time } & \multicolumn{3}{|l|}{ Petioles } & \multicolumn{3}{|c|}{ Leaves } \\
\hline & Number & Callus & $\begin{array}{l}\text { Callus rate } \\
\text { (\%) }\end{array}$ & Number & Callus & $\begin{array}{l}\text { Callus rate } \\
(\%)\end{array}$ \\
\hline$O D_{600}=0.6 / 5 \mathrm{~min}$ & $\begin{array}{l}35.33 \pm \\
0.58\end{array}$ & $\begin{array}{l}6.33 \pm \\
0.58\end{array}$ & $\begin{array}{l}17.91 \pm \\
1.33\end{array}$ & $40 \pm 1$ & $\begin{array}{l}4.33 \pm \\
0.58\end{array}$ & $\begin{array}{l}10.84 \pm \\
1.46\end{array}$ \\
\hline$O D_{600}=0.6 / 10 \mathrm{~min}$ & $39 \pm 1$ & $\begin{array}{l}13.33 \pm \\
0.58\end{array}$ & $34.23 \pm 2.3$ & $39 \pm 2$ & $7 \pm 1$ & $17.89 \pm 1.6$ \\
\hline$O D_{600}=1.0 / 5 \mathrm{~min}$ & $\begin{array}{l}43.33 \pm \\
1.5\end{array}$ & $10 \pm 1$ & $23.04 \pm 1.5$ & $\begin{array}{l}33 \pm \\
2.65\end{array}$ & $\begin{array}{l}10.33 \pm \\
1.5\end{array}$ & $31.23 \pm 2.6$ \\
\hline $\mathrm{OD}_{600}=1.0 / 10 \mathrm{~min}$ & $37 \pm 1$ & $8 \pm 1$ & $\begin{array}{l}21.61 \pm \\
2.44\end{array}$ & $\begin{array}{l}34.67 \pm \\
52\end{array}$ & $7 \pm 2$ & $\begin{array}{l}19.98 \pm \\
4.35\end{array}$ \\
\hline
\end{tabular}

A simple, rapid Agrobacterium-mediated genetic transformation system was established for $A$. pumila. The genetic transformation for petiole and leaf explants was carried out according to the following protocol: the petiole explants were first infected in an Agrobacterium suspension with $\mathrm{OD}_{600}$ at 0.6 for 10 min (Fig. 4a) and then co-cultured for $2 \mathrm{~d}$ in the dark (Fig. 4b). Adventitious shoot induction was performed for three months (Fig. 4c-f) and rooting induction for two months (Fig. $4 \mathrm{~g}-\mathrm{i}$ ), to allow for further seedling development (Fig. 4h, i), and transgenic A. pumila plants were eventually obtained (Fig. 4j, k).

The leaf explants were infected in the Agrobacterium suspension with $\mathrm{OD}_{600}$ at 1.0 for 5 min (Fig. 5a) and co-cultured in the dark for $2 \mathrm{~d}$ (Fig. 5b). Adventitious shoots were induced for three months (Fig. 5c, d) and rooting induction for two months (Fig. 5e). After seedling development (Fig. 5f), transgenic $A$. pumila plants were eventually obtained.

Identification of positive plants and analysis of ApP5CS1.1 gene expression

Using transgenic plant leaf genomic DNA as a template for PCR amplification, bands of the expected size could be amplified in the transgenic plants, suggesting that the ApP5CS1.1 gene was successfully transferred into A. pumila (Fig. 6a). Gene expression analysis by qRT-PCR showed that the ApP5CS1.1 gene was up-regulated to varying degrees in the transgenic plants tested. In the three different transgenic lines, the expression level of ApP5CS1.1 was 7.68, 3.27, and 1.27 times that of the wild-type plant, respectively (Fig. 6b). This result confirmed that the expression of ApP5CS1.1 was differentially overexpressed in the different transgenic lines. 


\section{Discussion}

The selection of plant explants is the key to adventitious shoot regeneration. To date, there have been reports of regeneration of different explants using plant apical meristems (Agrawal et al. 1997), stem tips (Sidky 2017), cotyledons (Wright et al. 2006), roots (Valvekens et al. 1988), leaf segments (Meijer et al. 1985), petioles (Kumar et al. 2015; Gambhir et al. 2017), and hypocotyls (Roussy et al. 1996). In this study, we used leaf and petiole explants of flask cultivated seedlings, and the hypocotyls and roots of 8day-old seedlings for efficient adventitious shoot regeneration. It was found that calluses were generally formed either directly at the point of incision of the root and hypocotyl explants, on the cut surface of the cut end of the leaf or petiole, or along the side of the petiole and leaf explants. Previous studies have shown that different explants and explants of different ages will affect the speed and efficiency of callus formation. For example, the hypocotyls of cabbage are more suitable for regeneration than the cotyledons (Gerszberg et al. 2015; Gambhir et al. 2017). We compared the regeneration ability of young roots and hypocotyls over the same time period. The callus induction rate $(99.42 \%)$ and adventitious shoot induction rate $(\mathbf{9 7 . 7 \%})$ of $\boldsymbol{A}$. pumila young roots were significantly higher than the rate for hypocotyls, which were $93.53 \%$ and $89.7 \%$, respectively. In addition, the time taken to form calluses (7.33 $\pm 0.48 \mathrm{~d})$ and adventitious shoots ( $32 \pm 2.15 \mathrm{~d}$ ) of young roots were also significantly shorter than for hypocotyls $(10.05 \pm 0.74 \mathrm{~d}$ and $59.05 \pm 2.16 \mathrm{~d}$, respectively) (Table 1 ).

Therefore, the 8-day-old seedling root explants of $A$. pumila were more suitable for inducing calluses and adventitious shoots than hypocotyl explants. The growth times of $A$. pumila leaf and petiole explants were longer than young roots and hypocotyls, with longer callus formation times. However, petiole and leaf adventitious shoot formation times ( $44.25 \pm 4.07 \mathrm{~d}$ and $41.95 \pm 2.37 \mathrm{~d}$, respectively) were shorter than for young roots and hypocotyls. The percentage of leaf explants forming calluses (92.5\%) was slightly lower than that of young roots $(97.7 \%)$. Also, the adventitious shoots appeared sooner on leaf explants than on petioles (Table 1). Adventitious shoots were produced on explants grown on MS medium containing growth regulators, and the shoots elongated and developed roots to produce plants which grew well in a mixture of nutrient soil and vermiculite $(w / w, 1: 1)$.

This study showed that the root, hypocotyl, leaf and petiole explants of $A$. pumila can be efficiently induced to form calluses on MS medium supplemented with 6-BA and NAA. These four types of explant can quickly induce callus within 1-2 weeks and can induce adventitious shoots within one to two months (Table 1). Arabidopsis pumila plants have a large quantity of leaf and petiole tissues, thus providing excellent explants for Agrobacterium-mediated genetic transformation experiments. The concentration of Agrobacterium and the infection time usually have significant effects on the ease of infection of explants (Han et al. 2013; Movahedi et al. 2014). The most suitable Agrobacterium concentration and infection time required for the infection of petiole and leaf explants are different. The callus rate of petiole explants and leaf explants reached $34.23 \%$ and $31.23 \%$ with an Agrobacterium infection solution of $\mathrm{OD}_{600}$ at 0.6 and 1.0 , and an infection time of $10 \mathrm{~min}$ and $5 \mathrm{~min}$, respectively. In this study we performed 35S:ApP5CS1.1 genetic transformation on petiole and leaf explants of $A$. pumila, and successfully obtained transgenic generation plants. A qRT-PCR analysis showed that the ApP5CS1.1 gene 
were significantly differentially expressed in the two lines (Fig. 6), which provides a foundation for subsequent in-depth studies of the function of the ApP5CS1.1 gene.

We compared the regeneration capacity of $A$. pumila roots, hypocotyls, leaves, and petioles. The induction time of root adventitious shoots was the shortest and the induction rate was the highest when grown on MS medium with $0.5 \mathrm{mg} / \mathrm{L}$ 6-BA and $0.1 \mathrm{mg} / \mathrm{L}$ NAA added. We did not use different hormone concentrations and parameter combinations in this study, and this will be the subject of future investigations. There are problems with the process of Agrobacterium transformation of petioles and leaf explants, such as the ease of contamination and slow callus formation. Future work will further improve and optimize the $A$. pumila regeneration cultivation and genetic transformation systems. Our findings suggested that our regeneration system is feasible. Using the four different explants of $A$. pumila (roots, hypocotyls, leaves, and petioles), the number of regenerated seedlings can be easily counted. Transgenic plants can be obtained by genetic transformation of leaves and petioles. These results further indicated that $\boldsymbol{A}$. pumila is a suitable model material for studying the adaptations of ephemeral plants to the environment, and provides a basis for experiments to identify the stress tolerance genes of ephemeral plants and explore the biological mechanisms behind rapid growth and development as adaptions to the unique desert climate in Xinjiang.

\section{Abbreviations}

\begin{tabular}{ll} 
MS & Murashige and Skoog \\
\hline 6-BA & 6-Benzylaminopurine \\
\hline NAA & a-Naphthalene acetic acid \\
\hline Carb & Carbenicillin \\
\hline P5CS1 & delta-1-pyrroline-5-carboxylic acid synthase 1 \\
\hline qRT-PCR & Quantitative real-time PCR
\end{tabular}

\section{Declarations}

Funding

This work is supported by the grants from the National Natural Science Foundation of China (U1303302), the Shihezi University International Cooperation Program (GJHZ201806), the Academic Leaders of Anhui University of Science and Technology Introduction Starting Fund (NXYJ202001), and the Research and Innovation Project of Postgraduates in Xinjiang Uygur Autonomous Region (XJ2019G083).

Authors' Contributions

$\mathrm{XH}$ and $\mathrm{YJ}$ conceived and designed research. $\mathrm{YJ}$ and $\mathrm{LG}$ conducted the experiments. DL, $\mathrm{YL}$, and HA analyzed the data and revise the manuscript. All authors read and approved the manuscript. 
Compliance with ethical standards

Competing interests The authors declare no competing interests.

Ethical approval This article does not contain any studies with human participants or animals performed by any of the authors.

\section{References}

1. Ali M, Mujib A, Tonk D, Zafar N (2017) Plant regeneration through somatic embryogenesis and genome size analysis of Coriandrum sativum L. Protoplasma 254(1):343-352

2. Anton DB, Guzman FL, Vetö NM, Krause FA, Kulcheski FR, Coelho APD, Duarte GL, Margis R, Dillenburg LR, Turchetto-Zolet AC (2020) Characterization and expression analysis of P5CS( $\triangle 1$ pyrroline-5-carboxylate synthase) gene in two distinct populations of the Atlantic Forest native species Eugenia uniflora L. Mol Biol Rep 47(2):1033-1043

3. Agrawal DC, Banerjee AK, Kolala RR, Dhage AB, Kulkarni AV, Nalawade SM, Hazra S, Krishnamurthy KV (1997) In vitro induction of multiple shoots and plant regeneration in cotton (Gossypium hirsutum L.). Plant Cell Rep 16(9):647-652

4. Bertier LD, Ron M, Huo H, Bradford KJ, Britt AB, Michelmore RW (2018) High-resolution analysis of the efficiency, heritability, and editing outcomes of CRISPR/Cas9-induced modifications of NCED4 in Lettuce (Lactuca sativa). G3 (Bethesda) 8(5):1513-1521

5. Bömer M, Rathnayake Al, Visendi P, Sewe SO, Sicat JPA, Silva G, Kumar PL, Seal SE (2019) Tissue culture and next-generation sequencing: A combined approach for detecting yam (Dioscorea spp.) viruses. Physiol Mol Plant Pathol 105:54-66

6. Bruce MA, Shoup Rupp JL (2019) Agrobacterium-mediated transformation of Solanum tuberosum L., Potato. Methods Mol Biol 1864:203-223

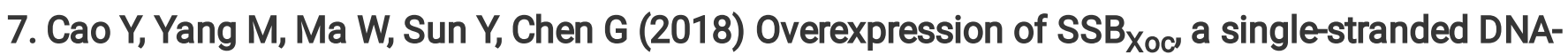
binding protein from Xanthomonas oryzae pv. oryzicola, enhances plant growth and disease and salt stress tolerance in transgenic Nicotiana benthamiana. Front Plant Sci 9:953

8. Cha TS, Yee W, Aziz A (2012) Assessment of factors affecting Agrobacterium-mediated genetic transformation of the unicellular green alga, Chlorella vulgaris. World J Microbiol Biotechnol 28(4):1771-1779

9. Feng C, Yuan J, Wang R, Liu Y, Birchler JA, Han F (2016) Efficient targeted genome modification in maize using CRISPR/Cas9 system. J Genet Genomics 43(1):37-43

10. Fossi M, Amundson K, Kuppu S, Britt A, Comai L (2019) Regeneration of Solanum tuberosum plants from protoplasts induces widespread genome instability. Plant Physiol 180(1):78-86

11. Gasparis S (2017) Agrobacterium-mediated transformation of leaf base segments. Methods Mol Biol 1536:95-111 
12. Garrocho-Villegas V, de Jesús-Olivera MT, Quintanar ES (2012) Maize somatic embryogenesis: recent features to improve plant regeneration. Methods Mol Biol 877:173-182

13. Gambhir G, Kumar P, Srivastava DK (2017) High frequency regeneration of plants from cotyledon and hypocotyl cultures in Brassica oleracea cv. Pride of India Biotechnol Rep (Amst) 15:107-113

14. Gerszberg A, Hnatuszko-Konka K, Kowalczyk T (2015) In vitro regeneration of eight cultivars of Brassica oleracea var. capitata. In Vitro Cell Dev Biol Plant 51(1):80-87

15. Han X, Ma S, Kong X, Takano T, Liu S (2013) Efficient Agrobacterium-mediated transformation of hybrid Poplar Populus davidiana Dodex Populus bollena Lauche. Int J Mol Sci 14(2):2515-2528

16. Hiei Y, Komari T (2008) Agrobacterium-mediated transformation of rice using immature embryos or calli induced from mature seed. Nat Protoc 3(5):824-834

17. Huang X, Yang L, Jin Y, Lin J, Liu F (2017) Generation, annotation, and analysis of a large-scale expressed sequence tag library from Arabidopsis pumila to explore salt-responsive genes. Front Plant Sci 8:955

18. Hu T, Metz S, Chay C, Zhou HP, Biest N, Chen G, Cheng M, Feng X, Radionenko M, Lu F, Fry J (2003) Agrobacterium-mediated large-scale transformation of wheat (Triticum aestivum $\mathrm{L}$.) using glyphosate selection. Plant Cell Rep 21(10):1010-1019

19. Imin N, Nizamidin M, Daniher D, Nolan KE, Rose RJ, Rolfe BG (2005) Proteomic analysis of somatic embryogenesis in Medicago truncatula. Explant cultures grown under 6-benzylaminopurine and 1naphthaleneacetic acid treatments. Plant Physiol 137(4):1250-1260

20. Jin Y, Liu F, Huang W, Sun Q, Huang X (2019) Identification of reliable reference genes for qRT-PCR in the ephemeral plant Arabidopsis pumila based on full-length transcriptome data. Sci Rep 9(1):8408

21. Kagami H, Taguchi K, Arakawa T, Kuroda Y, Tamagake H, Kubo T (2016) Efficient callus formation and plant regeneration are heritable characters in sugar beet (Beta vulgaris L.). Hereditas 153:12

22. Kumar P, Srivastava DK (2015) High frequency organogenesis in hypocotyl, cotyledon, leaf and petiole explants of broccoli (Brassica oleracea L. var. italica), an important vegetable crop. Physiol Mol Biol Plants 21(2):279-285

23. Kuriyama T, Shimada S, Matsui M (2019) Improvement of Agrobacterium-mediated transformation for tannin-producing Sorghum. Plant Biotechnol (Tokyo) 36(1):43-48

24. Lee K, Eggenberger AL, Banakar R, McCaw ME, Zhu H, Main M, Kang M, Gelvin SB, Wang K (2019) CRISPR/Cas9-mediated targeted T-DNA integration in rice. Plant Mol Biol 99(4-5):317-328

25. Li M, Li X, Zhou Z, Wu P, Fang M, Pan X, Lin Q, Luo W, Wu G, Li H (2016) Reassessment of the four yield-related genes Gn1a, DEP1, GS3, and IPA1 in rice using a CRISPR/Cas9 system. Front Plant Sci 7:377

26. Li M, Cheng C, Zhang X, Zhou S, Li L, Yang S (2019) Overexpression of pear (Pyrus pyrifolia) CAD2 in tomato affects lignin content. Molecules 24(14):2595

27. Livak KJ, Schmittgen TD (2001) Analysis of relative gene expression data using real-time quantitative PCR and the 2(-Delta Delta C(T)) Method. Methods 25(4):402-408 
28. Loyola-Vargas VM, Ochoa-Alejo N (2018) An introduction to plant tissue culture: advances and perspectives. Methods Mol Biol 1815:3-13

29. Lu X, Tang K, Li P (2016) Plant metabolic engineering strategies for the production of pharmaceutical terpenoids. Front Plant Sci 7:1647

30. Meijer EG, Brown DC (1985) Screening of diploid Medicago sativa germplasm for somatic embryogenesis. Plant Cell Rep 4(5):285-288

31. Movahedi A, Zhang J, Amirian R, Zhuge Q (2014) An efficient Agrobacterium-mediated transformation system for poplar. Int J Mol Sci 15(6):10780-10793

32. Oosumi T, Gruszewski HA, Blischak LA, Baxter AJ, Wadl PA, Shuman JL, Veilleux RE, Shulaev V (2006) High-efficiency transformation of the diploid Strawberry (Fragaria vesca) for functional genomics. Planta 223(6):1219-1230

33. Prasad B, Vadakedath N, Jeong HJ, General T, Cho MG, Lein W (2014) Agrobacterium tumefaciensmediated genetic transformation of haptophytes (Isochrysis species). Appl Microbiol Biotechnol 98(20):8629-8639

34. Raza G, Singh MB, Bhalla PL (2017) In Vitro plant regeneration from commercial cultivars of soybean. Biomed Res Int 2017:7379693

35. Raza G, Singh MB, Bhalla PL (2019) Somatic embryogenesis and plant regeneration from commercial soybean cultivars. Plants (Basel) 9(1):38

36. Roussy I, Dubois F, Sangwan RS, Sangwan-Norreel BS (1996) In planta 2,3,5 truodobenzoic acid treatment promotes high frequency and routine in vitro regeneration of sugarbeet (Beta vulgaris $L$.) plants. Plant Cell Rep 16(3-4):142-146

37. Sadeq MA, Pathak MR, Salih AA, Abido M, Abahussain A (2016) In vitro regeneration of endangered medicinal plant Heliotropium kotschyi (Ramram). Methods Mol Biol 1391:103-112

38. Saika H, Toki S (2010) Mature seed-derived callus of the model indica rice variety Kasalath is highly competent in Agrobacterium-mediated transformation. Plant Cell Rep 29(12):1351-1364

39. Shi ZY, Feng G, Christie P, Li XL (2006) Arbuscular mycorrhizal status of spring ephemerals in the desert ecosystem of Junggar Basin, China. Mycorrhiza 16(4):269-275

40. Sidky R (2017) Optimized direct organogenesis from shoot tip explants of date palm. Methods Mol Biol 1637:37-45

41. Song C, Lu L, Guo Y, Xu H, Li R (2019) Efficient Agrobacterium-mediated transformation of the commercial hybrid poplar Populus Alba x Populus glandulosa Uyeki. Int J Mol Sci 20(10):2594

42. Soyk S, Müller NA, Park SJ, Schmalenbach I, Jiang K, Hayama R, Zhang L, Van Eck J, JiménezGómez JM, Lippman ZB (2017) Variation in the flowering gene SELF PRUNING 5 G promotes dayneutrality and early yield in tomato. Nat Genet 49(1):162-168

43. Srivastava V, Underwood JL, Zhao S (2017) Dual-targeting by CRISPR/Cas9 for precise excision of transgenes from rice genome. Plant Cell Tissue Org 129:153-160

44. Szabados L, Savouré A (2010) Proline: a multifunctional amino acid. Trends Plant Sci 15(2):89-97 
45. Tatsis EC, O'Connor SE (2016) New developments in engineering plant metabolic pathways. Curr Opin Biotechnol 42:126-132

46. Tu W, Li Y, Liu W, Wu L, Xie X, Zhang Y, Wilhelm C, Yang C (2016) Spring ephemerals adapt to extremely high light conditions via an unusual stabilization of photosystem II. Front Plant Sci 6:1189

47. Valvekens D, Van Montagu M, Van Lijsebettens M (1988) Agrobacterium tumefaciens-mediated transformation of Arabidopsis thaliana root explants by using kanamycin selection. Proc Natl Acad Sci U S A 85(15):5536-5540

48. Wang M, Sun R, Wang Q, Zhang B (2019) Overexpression of miRNA in cotton via AgrobacteriumMediated transformation. Methods Mol Biol 1902:223-231

49. Wang Y, Cheng X, Shan Q, Zhang Y, Liu J, Gao C, Qiu JL (2014) Simultaneous editing of three homoeoalleles in hexaploid bread wheat confers heritable resistance to powdery mildew. Nat Biotechnol 32(9):947-951

50. Weckx S, Inzé D, Maene L (2019) Tissue culture of oil palm: finding the balance between mass propagation and somaclonal variation. Front Plant Sci 10:722

51. Wickramasuriya AM, Dunwell JM (2015) Global scale transcriptome analysis of Arabidopsis embryogenesis in vitro. BMC Genom 16(1):301

52. Wright E, Dixon RA, Wang ZY (2006) Medicago truncatula transformation using cotyledon explants. Methods Mol Biol 343:129-135

53. Yang L, Jin Y, Huang W, Sun Q, Liu F, Huang X (2018) Full-length transcriptome sequences of ephemeral plant Arabidopsis pumila provides insight into gene expression dynamics during continuous salt stress. BMC Genom 19(1):717

54. Zhao YX, Wei YL, Zhao P, Xiang CB, Xu F, Li C, Huang XZ (2013) Construction of a cDNA library from the ephemeral plant Olimarabidopsis pumila and preliminary analysis of expressed sequence tags. $Z$ Naturforsch C J Biosci 68(11-12):499-508

55. Zhong H, Elumalai S, Nalapalli S, Richbourg L, Prairie A, Bradley D, Dong S, Su XJ, Gu W, Strebe T, Shi L, Que Q (2018) Advances in Agrobacterium-mediated maize transformation. Methods Mol Biol 1676:41-59

\section{Figures}



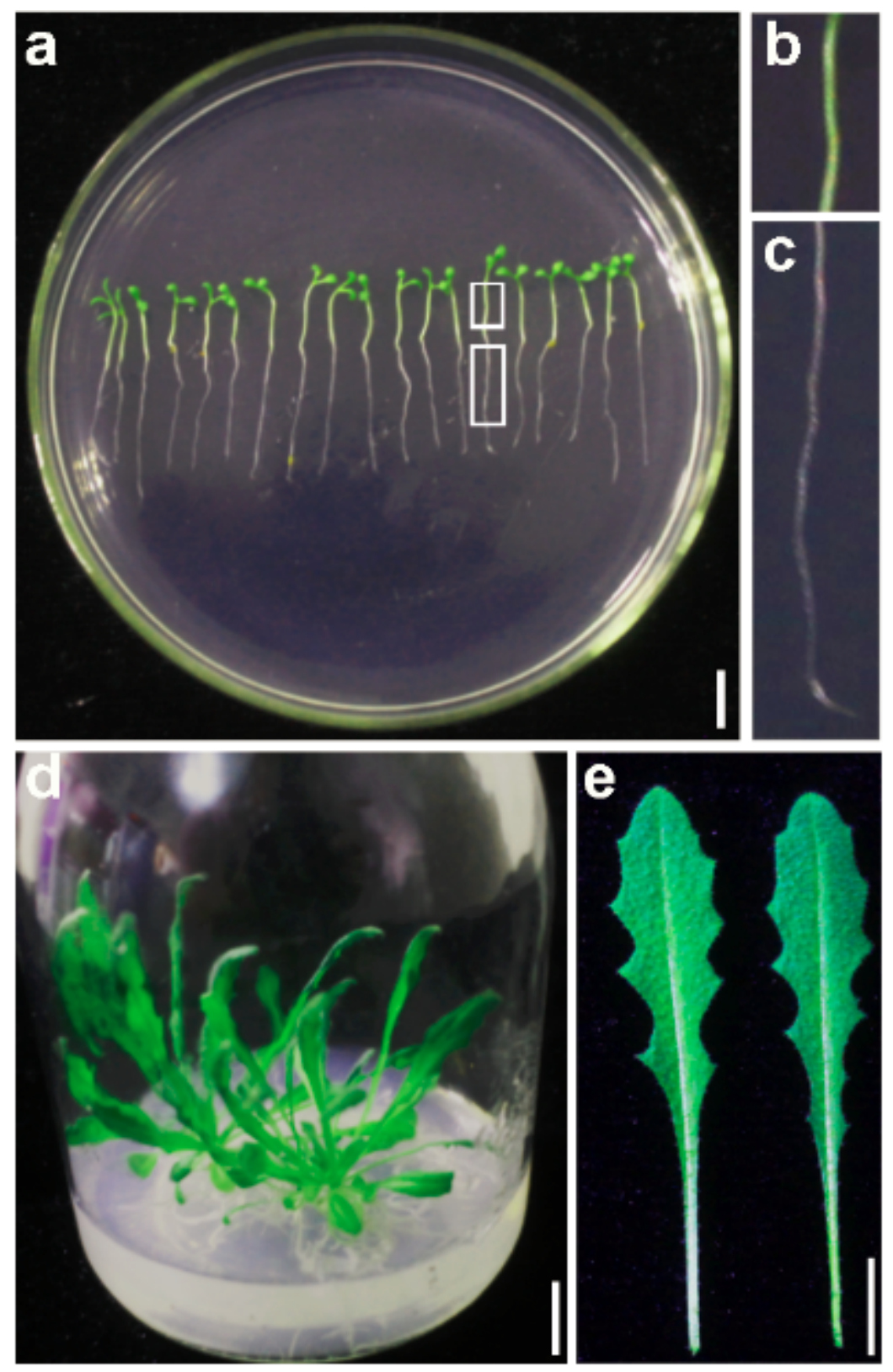

Figure 1

Observation on different explants of Arabidopsis pumila during greenhouse cultivation. a The seedlings were grown on MS medium for $8 \mathrm{~d}$. b and $c$ are enlarged images of hypocotyls and young roots of seedlings in a plot, respectively. $\mathrm{d}$ A. pumila seedlings were cultured in greenhouse for $30 \mathrm{~d}$. e Leaves and petioles of A. pumila. Scale bar, $1 \mathrm{~cm}$. 

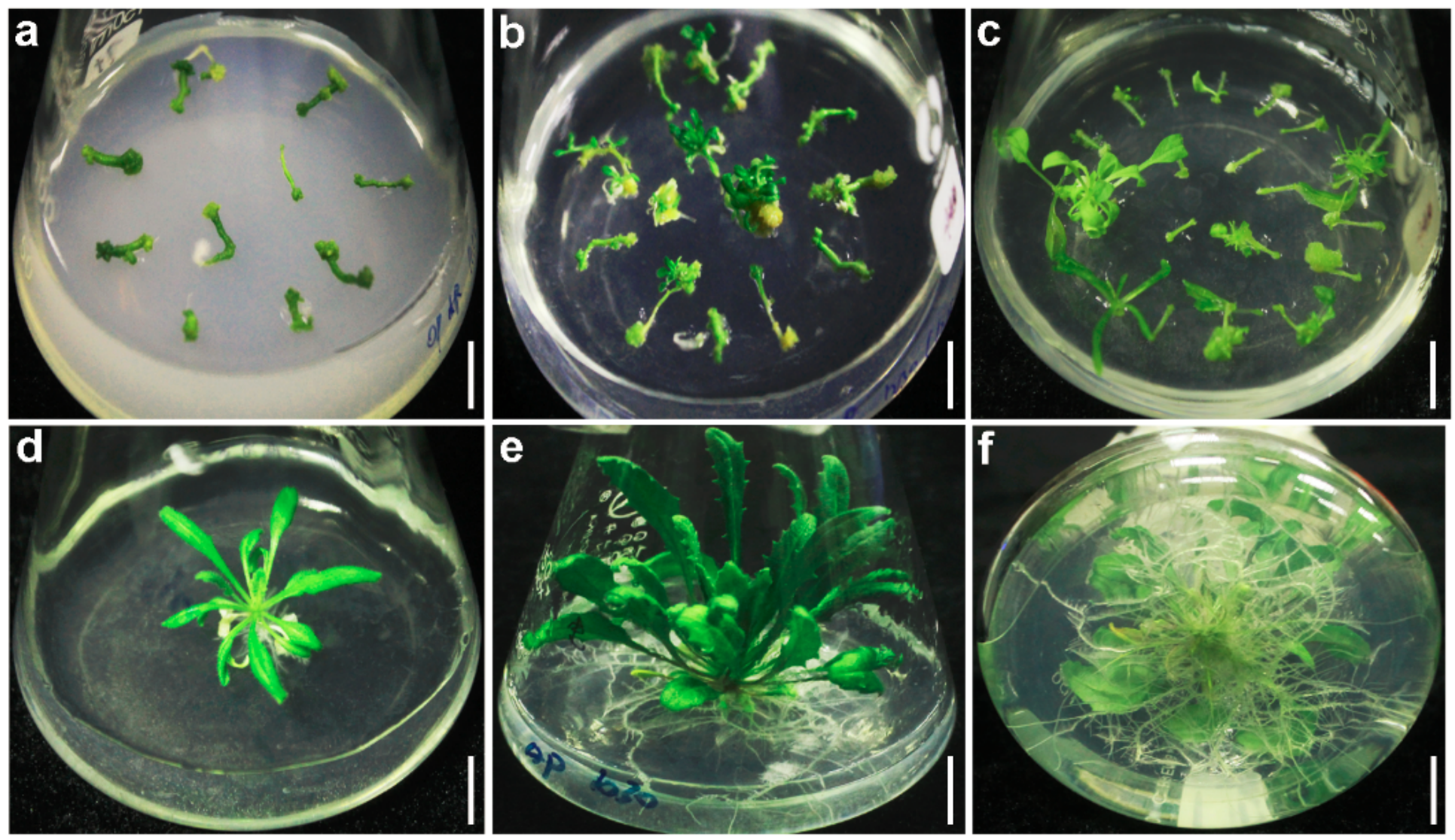

Figure 2

In vitro regeneration system of young root explants from Arabidopsis pumila. a Young root formed embryogenic callus. b Embryogenic callus induced adventitious shoots. c embryogenic callus formed a large number of adventitious shoots. $d$ Rooting medium to induce rooting. $e$ and $f$ Tissue culture seedlings grew a large number of roots. Scale bar, $1 \mathrm{~cm}$. 


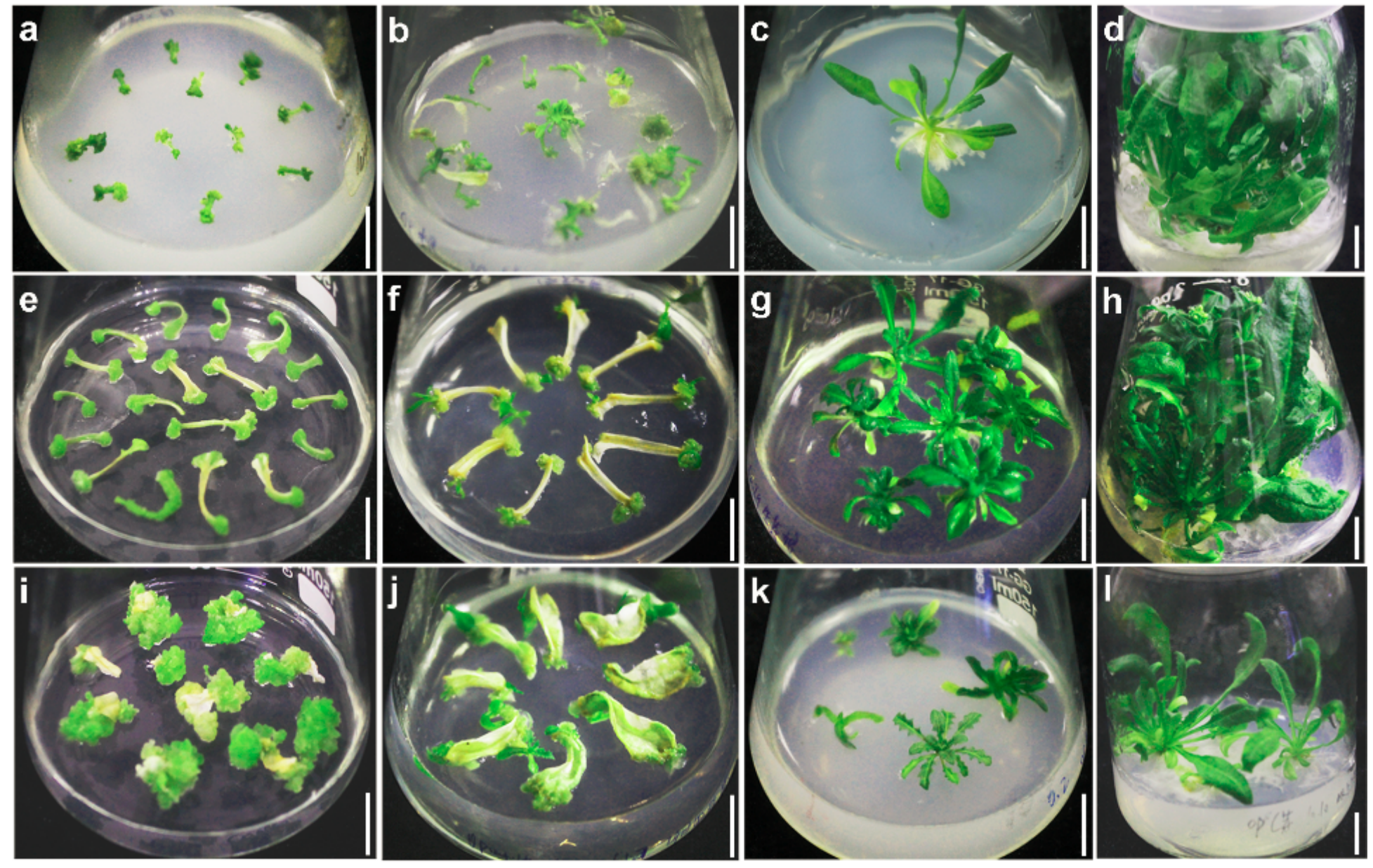

Figure 3

In vitro regeneration system of hypocotyl, petiole, and leaf explants from Arabidopsis pumila. a, e, i Calluses induced from hypocotyl, petiole, and leaf explants; b, $f, j$ Calluses formed adventitious shoots. c, g, $k$ Rooting medium to induce adventitious shoots rooting. $d, h$, I Regenerated seedlings induce a large number of roots. Scale bars, $1 \mathrm{~cm}$. 

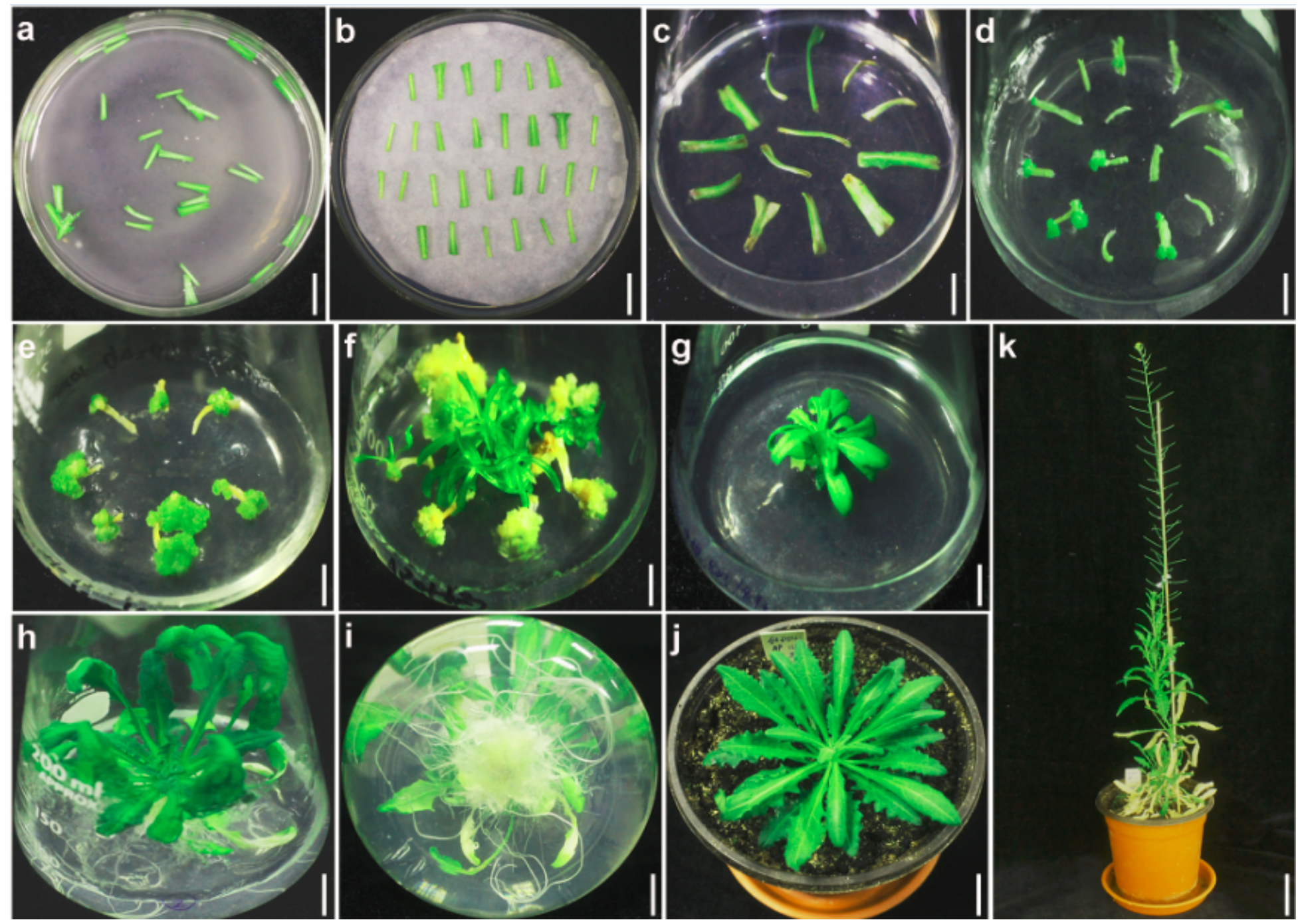

Figure 4

Agrobacterium-mediated transformation of 35S:ApP5CS1.1 into petiole explants of A. pumila. a Petioles were infected with $A$. tumefacienis with an OD600 value of 0.6 for $10 \mathrm{~min}$. b The petiole explants were cocultured for $2 \mathrm{~d}$. c Petiole explants were cultured for $7 \mathrm{~d}$ after infection. $\mathrm{d}$ The petiole explants formed calluses at $35 \mathrm{~d}$. e The calluses of petiole explants for $53 \mathrm{~d}$. $\mathrm{f}$ Petiole explants formed adventitious shoots at about 3 months. $g$ Rooting medium induced adventitious shoots rooting. $\mathrm{h}$ Adventitious shoots induced to form a large number of roots in 2 months and $15 \mathrm{~d}$. i Observation on the roots of transgenic seedlings. $j$ Transplanting to soil for growth. $k$ Adventitious shoots produced a large number of siliques. Scale bars in Fig. a-i represent $1 \mathrm{~cm}$, and scale bar represents $5 \mathrm{~cm}$ in the Fig. $\mathrm{k}$. 

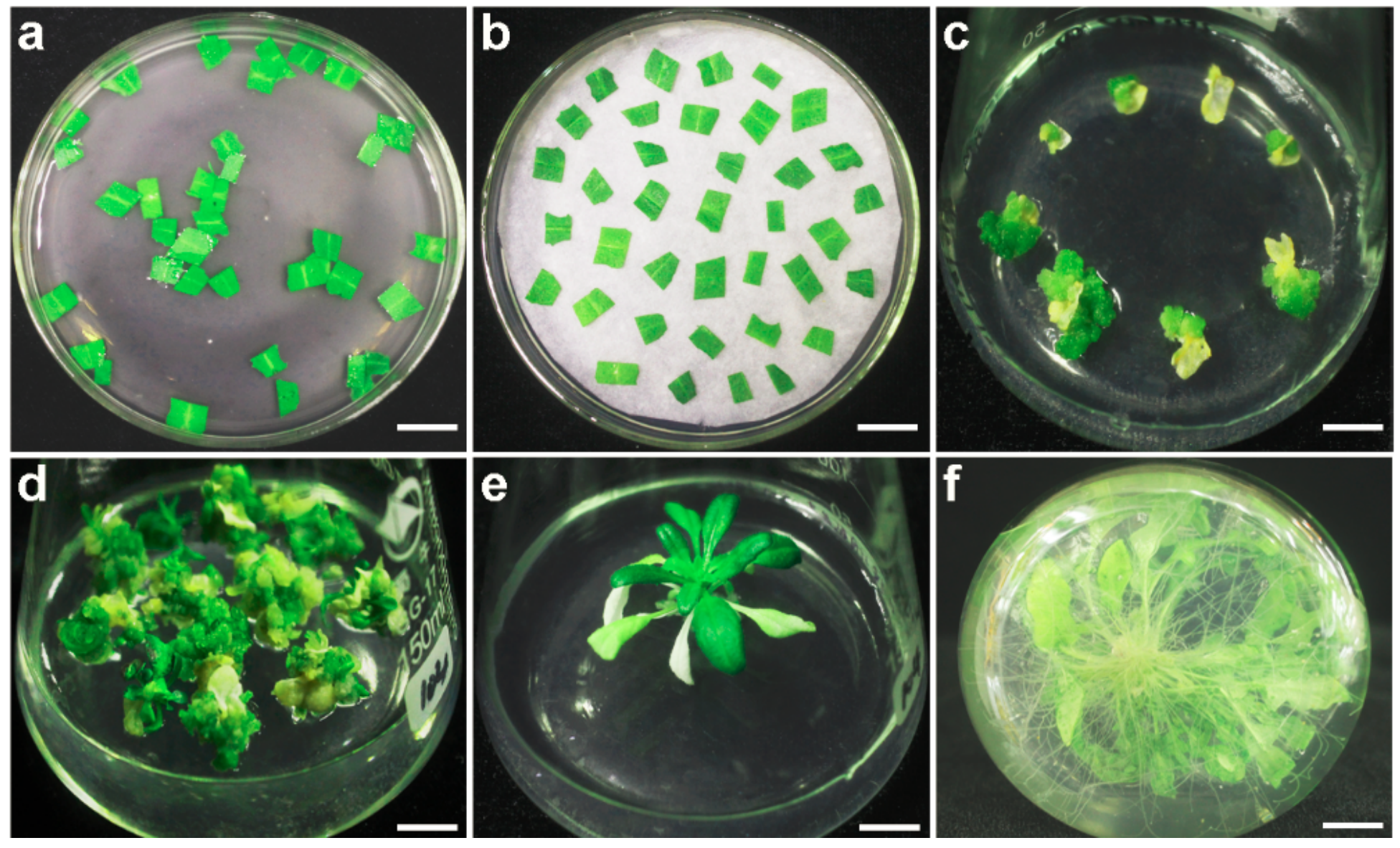

Figure 5

The flowchart of the Agrobacterium-mediated transformation system of 35S:ApP5CS1.1 into leaf explants of for A. pumila. a Leave explants were infected with A. tumefacien strain GV3101 harboring 35S:ApP5CS1.1 plasmids with an OD600 value of 1.0 for $5 \mathrm{~min}$. $b$ The leaf explants were co-culture for 2 d. c Callus status of leaf explants for $53 \mathrm{~d}$. $\mathrm{d}$ Leaf explants formed adventitious shoots at about three months and $20 \mathrm{~d}$. e Rooting medium induced adventitious shoots rooting. $f$ Adventitious shoots were induced to form a large number of roots in two months and $15 \mathrm{~d}$. Scale bars indicate $1 \mathrm{~cm}$. 


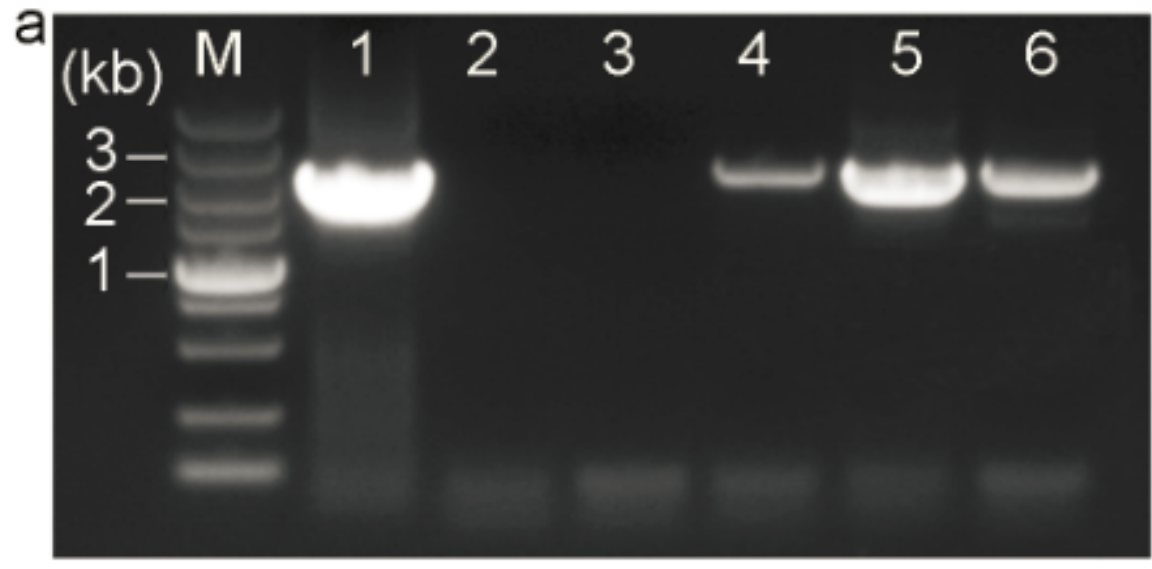

b

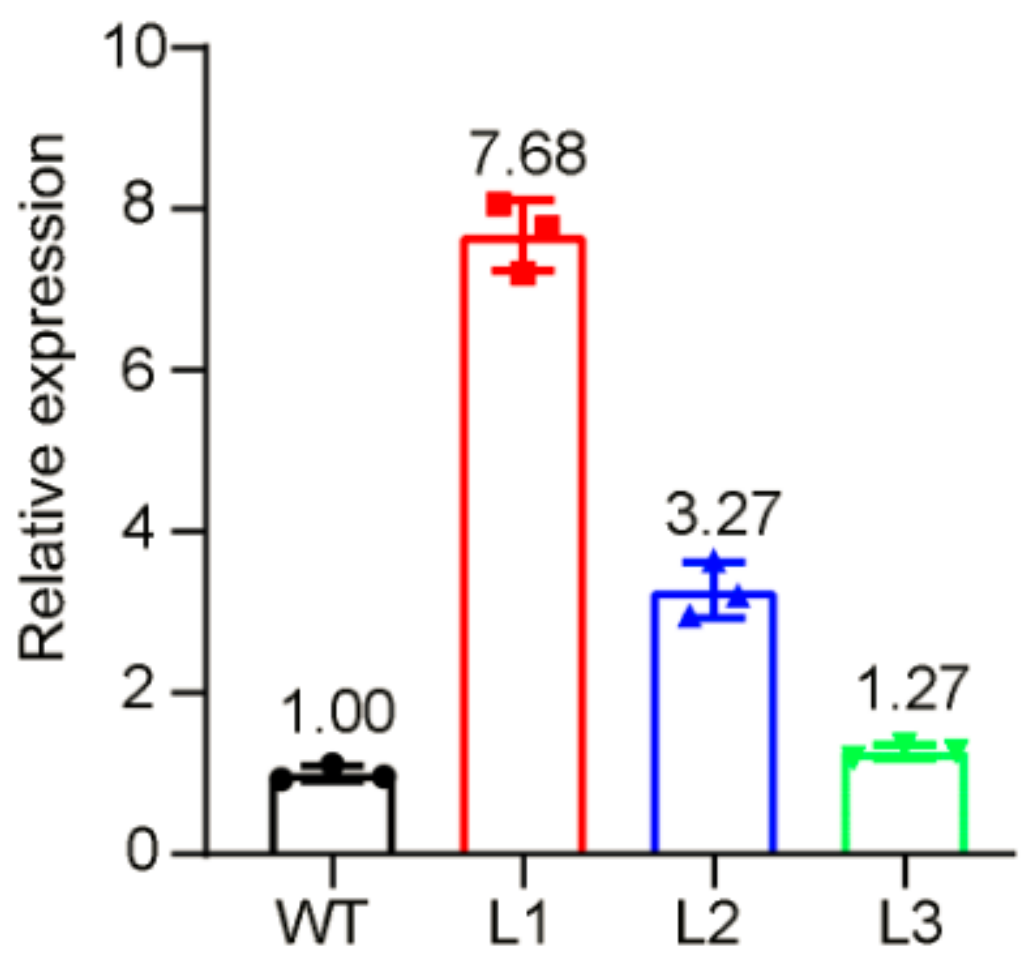

Figure 6

Gene expression analysis by qRT-PCR showed that the ApP5CS1.1 gene was up-regulated to varying degrees in the transgenic plants tested. In the three different transgenic lines, the expression level of ApP5CS1.1 was $7.68,3.27$, and 1.27 times that of the wild-type plant, respectively (Fig. 6b)

\section{Supplementary Files}

This is a list of supplementary files associated with this preprint. Click to download.

- Supplymentaryinformation.docx 